\title{
Stabilization of Soluble Proteins in Vitro by Heat Shock Proteins-Enriched Ammonium Sulfate Fraction from Soybean Seedlings
}

\author{
T. L. Jinn, Y. C. Yeh, Y. M. Chen and C. Y. Lin ${ }^{1}$ \\ Department of Botany, National Taiwan University, Taipei, Taiwan, R. O.C.
}

\begin{abstract}
The 70-100\% ammonium sulfate fraction of postribosomal supernatant of heat shocked soybean seedlings contained a high percentage of all of the heat shock proteins. The proteins in this fraction were resistant to heat denaturation, as judged by their unpelletability after heat treatment. Moreover, this fraction, when added to the postribosomal supernatant from control (nonheat shocked) seedlings, showed a significant ability to protect the control proteins from heat denaturation. Heated at $55^{\circ} \mathrm{C}$, some $50 \%$ of the control proteins, which were normally denatured after heat treatment, were protected for at least $1 \mathrm{~h}$ when heat shock proteins-enriched fraction was added. The degree of protection was proportional to the amount of heat shock proteins-enriched fraction added. However, when the ammonium sulfate fraction prepared from the seedlings with a heat treatment at $40^{\circ} \mathrm{C}$ for $3 \mathrm{~h}$ followed with a brief heat shock at $45^{\circ} \mathrm{C}$ which depleted most of the $15-18 \mathrm{kDa}$ and partial $68-70 \mathrm{kDa}, 24 \mathrm{kDa}$ and $22 \mathrm{kDa}$ heat shock proteins was added the effectiveness in preventing heat denaturation was lost. This suggests that the heat shock proteins of 15-18 kDa with those of 68-70 kDa and perhaps $24 \mathrm{kDa}$ and $22 \mathrm{kDa}$ are important for providing the protection from heat denaturation.
\end{abstract}

Key words: Heat shock protein - In vitro heat denaturation - Soybean seedling - Stabilization.

The induction of HSPs is a response to thermal stress in wide range of organisms (Schlesinger et al. 1982). When soybean seedlings are shifted from a normal growth temperature of $28^{\circ} \mathrm{C}$ to $40^{\circ} \mathrm{C}$, there is a dramatic change in the pattern of protein synthesis: a new set of proteins, the HSPs, is rapidly synthesized (Barnett et al. 1980, Key et al. 1981).

While the physiological function of HSPs has not been documented, their induction is correlated well with the thermotolerance developed in a time and temperature dependent manner. Based on this correlation it has been hypothesized that accumulation of HSPs is an essential component of the protection process from heat damage (Gerner and Schneider 1975, Li and Werb 1982, Loomis and Wheeler 1980, McAlister and Finkelstein 1980, Mitchell et al. 1979, Petersen and Mitchell 1981). The kinetics of association or localization of the HSPs during HS and

Abbreviations: AS, ammonium sulfate; DTT, dithiothreitol; HS, heat shock; HSPs, heat shock proteins; MW, molecular weight standard; PAGE, polyacrylamide gel electrophoresis; PMSF, phenylmethylsulfonyl fluoride; PRS, postribosomal supernatant.

${ }^{1}$ To whom correspondence should be addressed. of dissociation during recovery from HS in soybean seedlings ( $L$ in et al. 1984) are also consistent with the notion that this dynamic localization process (Arrigo et al. 1980, Arrigo and Ahmad-Zadeh 1981, Cooper and Ho 1987, Levinger and Varshvsky 1981, Mitchell and Lipps 1975, Velazquez et al. 1980, Vincent and Tanquay 1979) is important for thermoprotection during HS and for resumption of cellular activities after HS.

During the purification of HSPs from PRS of heat shocked soybean seedlings by AS fractionation, we recovered the whole set of HSPs in a 70-100\% AS fraction. Moreover, this fraction was very stable to heating (up to $65^{\circ} \mathrm{C}$ for $4 \mathrm{~h}$ ).

Minton et al. (1982) proposed a model for the biological role of HSPs by stabilizing nonspecifically other proteins which are highly susceptible to inactivation or denaturation by heat.

In this study we used the AS fraction enriched in HSPs to test the hypothesis of Minton et al. (1982).

\section{Materials and Methods}

Plant material-Soybean seeds (Glycine max cv. Taita Kaoshiung \#8) were germinated in rolls of moist paper 
towel at $28^{\circ} \mathrm{C}$ in a dark growth chamber.

Preparation of PRS-Two day-old seedlings $(3-4 \mathrm{~cm}$ in length) without cotyledons were incubated in a medium containing 1\% sucrose and $5 \mathrm{mM} \mathrm{K}$-phosphate (pH 6.0) in a shaking water bath. For labeling, fifty seedlings per sample were incubated in $10 \mathrm{ml}$ of the incubation medium at $28^{\circ} \mathrm{C}$ or $40^{\circ} \mathrm{C}$ for $3 \mathrm{~h}$, labeled the last $2.5 \mathrm{~h}$ with $300 \mu \mathrm{Ci}$ of ${ }^{3} \mathrm{H}$-leucine in the presence of $50 \mu \mathrm{g} / \mathrm{ml}$ of chloramphenicol, and chased with $1 \mathrm{mM}$ leucine at $28^{\circ} \mathrm{C}$ for $4 \mathrm{~h}$. Labeled seedlings were rinsed thoroughly with $1 \mathrm{~mm}$ leucine before isolation of ribosomes. Seedlings were homogenized with a polytron equipped with PT-20 probe, in a medium contianing $0.5 \mathrm{M}$ sucrose, $0.2 \mathrm{M}$ Tris- $\mathrm{HCl}$ (pH 8.8), $30 \mathrm{~mm}$ $\mathrm{MgCl}_{2}, 0.1 \mathrm{M} \mathrm{KCl}, 1 \mathrm{mM}$ DTT, and $1 \mathrm{~mm}$ PMSF. The homogenate was filtered through a layer of Miracloth and centrifuged for $15 \mathrm{~min}$ at $23,000 \times \mathrm{g}$. Ribosomes were pelleted as described previously (Lin et al. 1984) but without the $1.7 \mathrm{M}$ sucrose cushion.

AS fractionation-PRS was fractionated into precipitates at 30\% saturation (AS I), 30-50\% saturation (AS II), 50-70\% saturation (AS III), and 70-100\% saturation (AS IV). The pellet from each fraction was dissolved in a medium containing $50 \mathrm{~mm}$ Tris- $\mathrm{HCl}$ (pH 8.0), $1 \mathrm{~mm}$ EDTA, $0.1 \%$ 2-mercaptoethanol, and the solution was dialyzed overnight against the same medium. All experimental procedures were carried out at $4^{\circ} \mathrm{C}$.

Measurement of labeled proteins and quantitative estimation of proteins-For measurement of ${ }^{3} \mathrm{H}$-proteins, a sample was blotted on $3 \mathrm{MM}$ filter paper and processed as described by Mans and Novelli (1961). For quantitative analysis of proteins Lowry et al. (1951) method was used.

Gel electrophoresis and fuorography of in vivo synthesized proteins-Labeled proteins were extracted with $50 \mathrm{~mm}$ Tris-HCl (pH 8.5), 2\% SDS, 2\% 2-mercaptoethanol, and $1 \mathrm{~mm}$ PMSF at room temperature. The extract was precipitated with five volumes of acetone and stored at $-20^{\circ} \mathrm{C}$ overnight. The precipitates were pelleted, dried, and dissolved in Laemmli's sample buffer for SDS-PAGE according to Laemmli (1970). For gel electro-phoresis equivalent amounts of protein samples were loaded unless otherwise specified. Fluorography of the gels was accomplished using ENHANCE (New England Nuclear) and Kodak film (XAR-5).

Assay for thermal denaturation of proteins-Protein samples (AS IV) ${ }^{3} \mathrm{H}$-labeled at $28^{\circ} \mathrm{C}$ or $40^{\circ} \mathrm{C}$ were heated at the indicated temperature for the indicated period with shaking and at the end of the assay, the denatured proteins were pelleted at $23,000 \times g$ for $15 \mathrm{~min}$. The undernatured proteins remaining in the supernatant were measured for radioactivity. For the assay of stabilization of proteins by HSPs-enriched AS IV, $28^{\circ} \mathrm{C}{ }^{3} \mathrm{H}$-protein samples mixed with non-labeled AS IV were incubated at $55^{\circ} \mathrm{C}$ for $30 \mathrm{~min}$ or $1 \mathrm{~h}$. After incubation the denatured ${ }^{3} \mathrm{H}$-proteins were pelleted at $23,000 \times g$ for $15 \mathrm{~min}$. The radioactivity in the pellets were measured after suspension in Laemmli's sample buffer.

\section{Results}

AS fractionation of $P R S$-Four different concentrations of AS, $0-30 \%$ (AS I), 30-50\% (AS II), $50-70 \%$ (AS III), and $70-100 \%$ (AS IV) were used to fractionate PRS. As shown in Table 1, the four AS fractionated PRS fractions differed little in protein distribution between samples from $28^{\circ} \mathrm{C}$ and from $40^{\circ} \mathrm{C}$. However, in terms of radioactivity distribution, the AS IV showed marked differences. The specific activity (cpm/mg proteins) of the AS IV from $40^{\circ} \mathrm{C}$ was about twice that from $28^{\circ} \mathrm{C}$ (Table 1). HSPs were shown to be enriched in $40^{\circ} \mathrm{C}$ AS IV through SDS-PAGE analysis and fluorography (Fig. 1A). The molecular weight of soybean HSPs are $90 \mathrm{kDa}$, $83 \mathrm{kDa}, 68-70 \mathrm{kDa}, 27 \mathrm{kDa}, 24 \mathrm{kDa}, 22 \mathrm{kDa}$ and $15-$ $18 \mathrm{kDa}$ shown in lane 2 of Fig. $1 \mathrm{~A}$ as shown by Key et al. (1981). The presence of $15-18 \mathrm{kDa}$ HSPs could be easily detected by Coomassie blue stain (Fig. 1B, lane 10). The AS IV from $40^{\circ} \mathrm{C}$ is therefore termed the HSPs-enriched fraction.

Table 1 AS fractionation of in vivo labeled ${ }^{3} \mathrm{H}$-proteins from $28^{\circ} \mathrm{C}$ and $40^{\circ} \mathrm{C}$ heat treated soybean seedlings

\begin{tabular}{|c|c|c|c|c|c|}
\hline \multirow{2}{*}{ AS } & & \multicolumn{2}{|c|}{$28^{\circ} \mathrm{C}$} & \multicolumn{2}{|c|}{$40^{\circ} \mathrm{C}$} \\
\hline & & $\mathrm{cpm}$ & $\mathrm{mg}$ & $\mathrm{cpm}$ & $\mathrm{mg}$ \\
\hline AS I & $(0-30 \%)$ & 181,000 & 2.68 & 257,000 & 2.53 \\
\hline AS II & $(30-50 \%)$ & $1,494,000$ & 23.68 & $2,351,000$ & 23.12 \\
\hline AS III & $(50-70 \%)$ & $4,664,000$ & 19.72 & $6,051,000$ & 19.04 \\
\hline AS IV & $(70-100 \%)$ & $2,160,000$ & 8.10 & $5,400,000$ & 8.51 \\
\hline
\end{tabular}

Fifty seedlings per sample were incubated in $10 \mathrm{ml}$ of the incubation medium at $28^{\circ} \mathrm{C}$ or at $40^{\circ} \mathrm{C}$ for $3 \mathrm{~h}$, labeled the last $2.5 \mathrm{~h}$ with $300 \mu \mathrm{Ci}$ of ${ }^{3} \mathrm{H}$-leucine and chased with $1 \mathrm{~mm}$ leucine at $28^{\circ} \mathrm{C}$ for $4 \mathrm{~h}$. The seedlings were harvested for isolation of PRS which were then subjected to AS fractionation. 
(A)
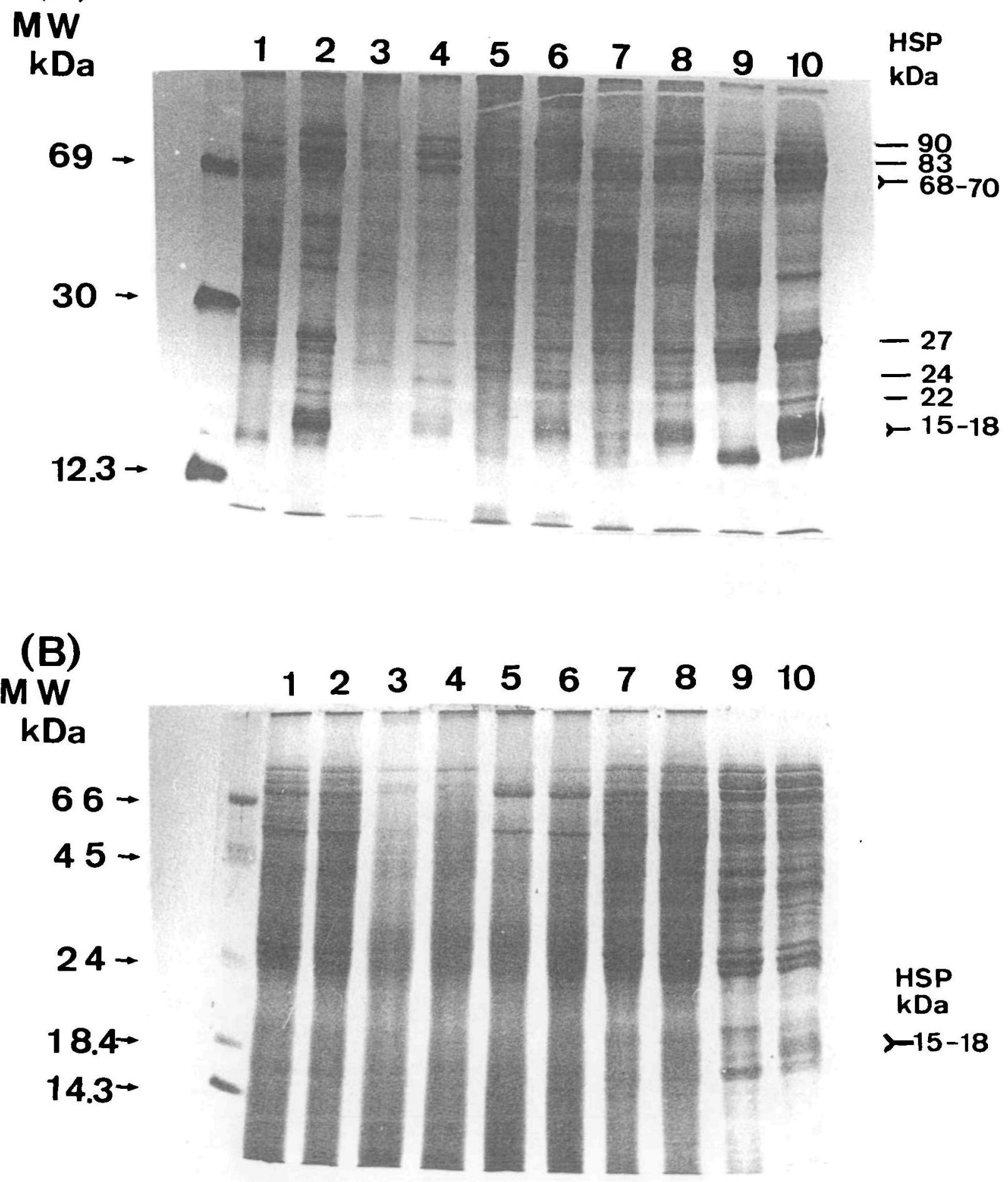

Fig. 1 (A) Fluorographs and (B) Coomassie blue stains of in vivo labeled proteins. After AS fractionation, the fractions were separated into protein components by SDS-PAGE. 1 and 2, total proteins; 3 and 4, AS I; 5 and 6, AS II; 7 and 8, AS III; 9 and 10, AS IV. $1,3,5,7$ and 9 are proteins from $28^{\circ} \mathrm{C}$ and $2,4,6,8$ and 10 are proteins from $40^{\circ} \mathrm{C}$. The MW are shown in the left lane of lane 1 . 
Table 2 Heat stability of AS IV fraction prepared from $28^{\circ} \mathrm{C}$ or $40^{\circ} \mathrm{C}$ heat treated seedlings

\begin{tabular}{|c|c|c|c|c|c|c|c|c|}
\hline \multirow{3}{*}{ AS IV } & \multicolumn{8}{|c|}{$\mathrm{cpm}$ in supernatant (undenatured proteins) } \\
\hline & \multicolumn{3}{|c|}{$65^{\circ} \mathrm{C}$} & \multicolumn{4}{|c|}{$77^{\circ} \mathrm{C}$} & \multirow{2}{*}{$\begin{array}{c}85^{\circ} \mathrm{C} \\
1 \mathrm{~h} \\
\end{array}$} \\
\hline & $\mathrm{Oh}$ & $1 \mathrm{~h}$ & $4 \mathrm{~h}$ & $0.5 \mathrm{~h}$ & $1 \mathrm{~h}$ & $2 \mathrm{~h}$ & $4 \mathrm{~h}$ & \\
\hline $28^{\circ} \mathrm{C}$ & $\begin{array}{c}15,202 \\
(100 \%)\end{array}$ & $\begin{array}{r}12,173 \\
(80 \%)\end{array}$ & $\begin{array}{c}8,749 \\
(58 \%)\end{array}$ & $\begin{array}{r}5,493 \\
(36 \%)\end{array}$ & $\begin{array}{r}4,495 \\
(30 \%)\end{array}$ & $\begin{array}{r}3,642 \\
(24 \%)\end{array}$ & $\begin{array}{r}3,137 \\
(21 \%)\end{array}$ & $\begin{array}{r}2,485 \\
(17 \%)\end{array}$ \\
\hline $40^{\circ} \mathrm{C}$ & $\begin{array}{c}36,064 \\
(100 \%)\end{array}$ & $\begin{array}{c}35,786 \\
(100 \%)\end{array}$ & $\begin{array}{c}35,576 \\
(100 \%)\end{array}$ & $\begin{array}{l}24,382 \\
(68 \%)\end{array}$ & $\begin{array}{l}24,326 \\
(67 \%)\end{array}$ & $\begin{array}{l}21,119 \\
(59 \%)\end{array}$ & $\begin{array}{l}16,589 \\
(50 \%)\end{array}$ & $\begin{array}{c}9,195 \\
(26 \%)\end{array}$ \\
\hline
\end{tabular}

${ }^{3} \mathrm{H}$-labeled proteins of $28^{\circ} \mathrm{C}$ or $40^{\circ} \mathrm{C}$ AS IV fraction in $0.9 \mathrm{ml}$ per sample (containing $1 \mathrm{mg}$ of proteins) were heated at indicated temperature and time priod, and $25 \mu$ d duplicate aliquots of the supernatant containing undenatured proteins were measured for radioactivity.

Heat stability of HSPs-enriched ASIV-We found the $40^{\circ} \mathrm{C}$ AS IV, HSPs-enriched fraction, to be very resistant to heat denaturation as measured by unpelletability after heating (remained soluble in the supernatant) (Table 2). For example, when the $40^{\circ} \mathrm{C}$ AS IV was subjected to $65^{\circ} \mathrm{C}$ for $4 \mathrm{~h} 100 \%$ of the label remained soluble. When the fraction was heated at $77^{\circ} \mathrm{C}$ for $0.5 \mathrm{~h}$ and $4 \mathrm{~h}$ about $32 \%$ and $50 \%$ of the label was found in the pellet respectively. On the other hand when the $28^{\circ} \mathrm{C}$ AS IV was heated at $65^{\circ} \mathrm{C}$ for $4 \mathrm{~h} 42 \%$ of the proteins was pelleted (denatured); when heated at $77^{\circ} \mathrm{C}$ for $4 \mathrm{~h} 79 \%$ of the labeled proteins was pelleted. The undenatured proteins remaining in the supernatant after the heating were analyzed by SDS-PAGE. We found that $15-18 \mathrm{kDa}$ were more stable, followed by $27 \mathrm{kDa}$, whereas $68-70 \mathrm{kDa}$, $83 \mathrm{kDa}$ show least stability (Fig. 2).

Protection ability of the $40^{\circ} \mathrm{C}$ AS IV (time and quantity)-Fig. 3A shows that the $40^{\circ} \mathrm{C}$ AS IV provided thermoprotection at $55^{\circ} \mathrm{C}$ during the $1 \mathrm{~h}$ incubation; the protection was about $50 \%$ higher than $28^{\circ} \mathrm{C}$ AS IV. When the temperature was at $65^{\circ} \mathrm{C}$, the $40^{\circ} \mathrm{C}$ AS IV provided better protection only during the first $30 \mathrm{~min}$. Fig. 3B provides evidence that the protection ability of the $40^{\circ} \mathrm{C}$ AS IV was proportional to the amount of proteins used.

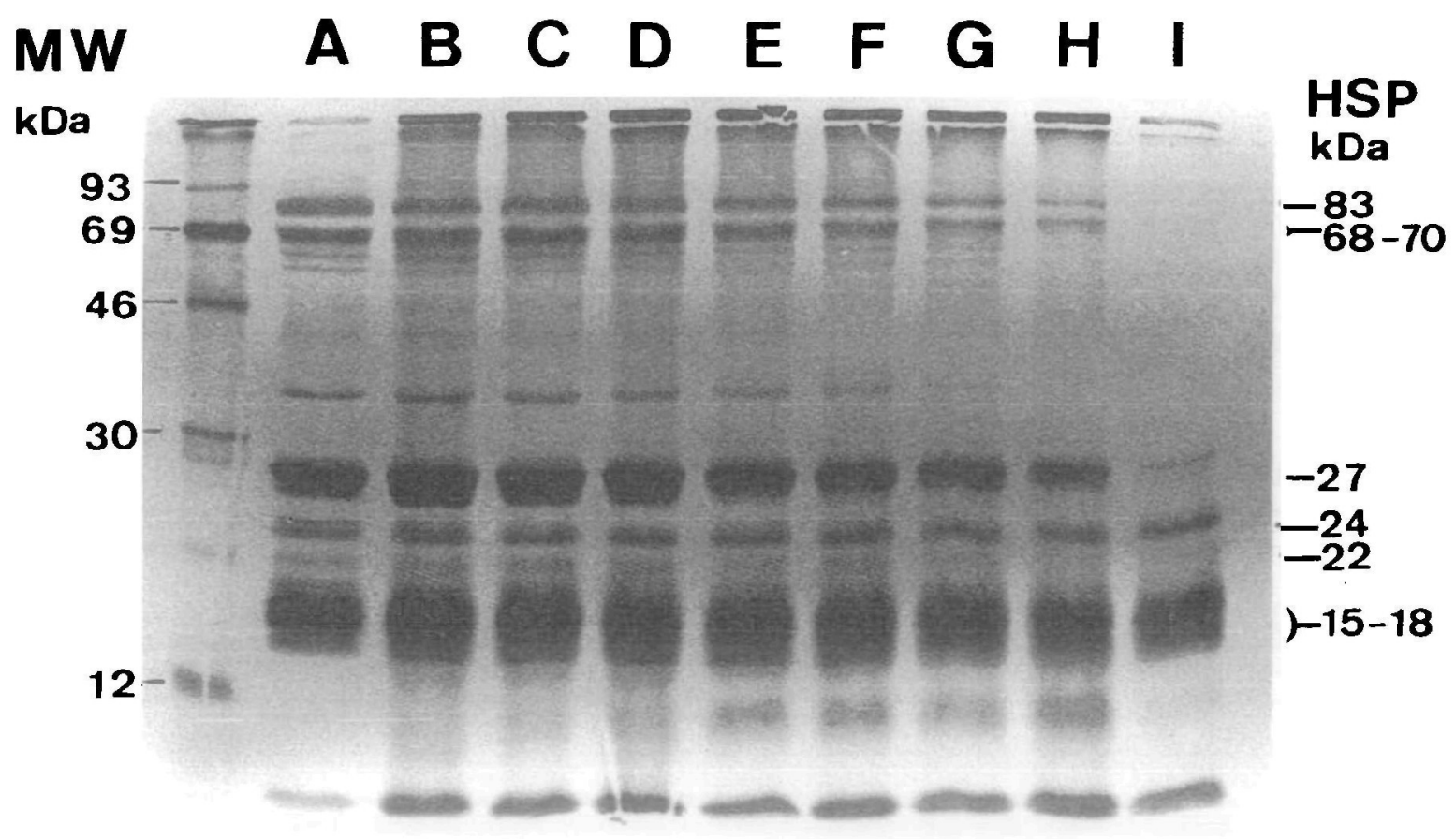

Fig. 2 Fluorographs of $40^{\circ} \mathrm{C}$ AS IV undenatured proteins remained in the supernatant after heat treatment by SDS-PAGE analysis (based on equivalent amounts of tissue). Heat treatment at $55^{\circ} \mathrm{C}$ for $0 \mathrm{~h} \mathrm{(A)}$ and $4 \mathrm{~h} \mathrm{(B);} \mathrm{at} 65^{\circ} \mathrm{C}$ for $1 \mathrm{~h} \mathrm{(C)}$ and $4 \mathrm{~h}(\mathrm{D})$; at $77^{\circ} \mathrm{C}$ for $0.5 \mathrm{~h} \mathrm{(E),} 1 \mathrm{~h} \mathrm{(F),} 2 \mathrm{~h}(\mathrm{G})$ and $4 \mathrm{~h} \mathrm{(H);} \mathrm{at} 85^{\circ} \mathrm{C}$ for $1 \mathrm{~h} \mathrm{(I).} \mathrm{The} \mathrm{MW} \mathrm{are} \mathrm{shown} \mathrm{in} \mathrm{the} \mathrm{left} \mathrm{lane} \mathrm{of} \mathrm{lane} 1$. 
(A)

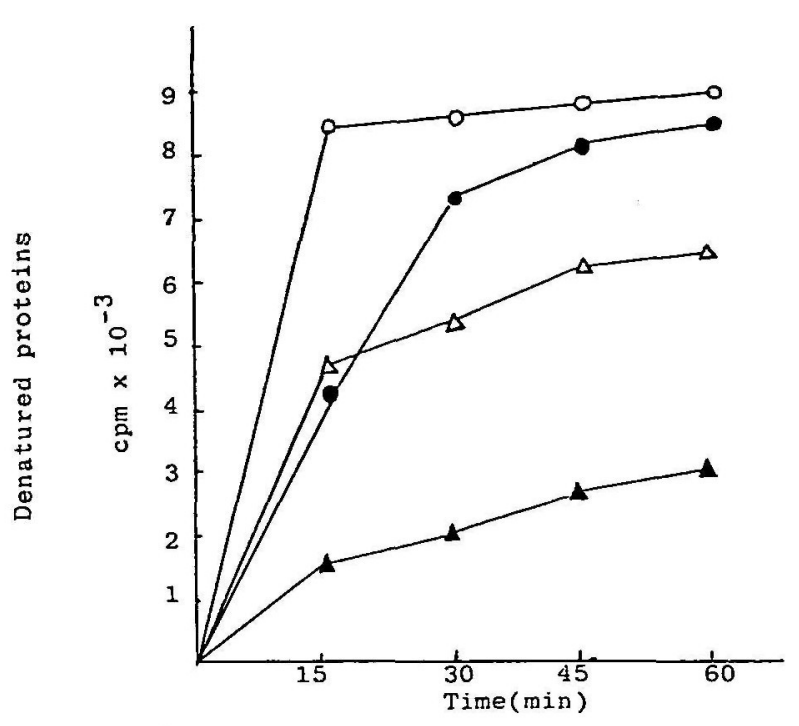

(B)

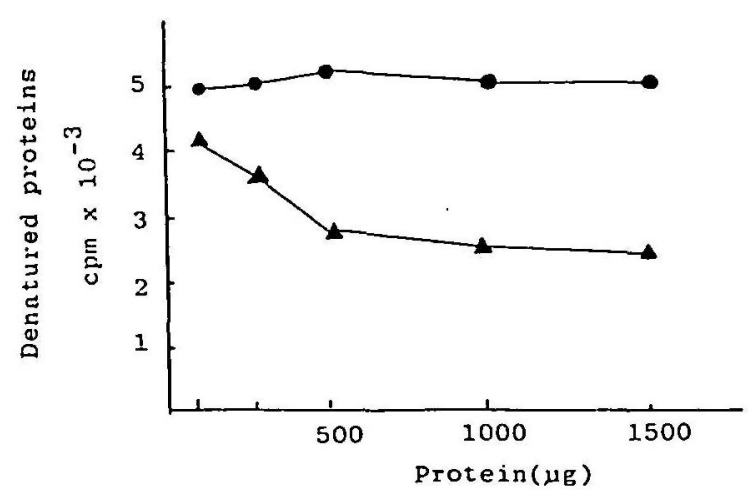

Fig. 3 (A) Time course of $28^{\circ} \mathrm{C}^{3} \mathrm{H}$-protein denaturation by heat treatment. To $1 \mathrm{ml}$ of $28^{\circ} \mathrm{C}{ }^{3} \mathrm{H}$-proteins (containing $202,300 \mathrm{cpm}$ and $2 \mathrm{mg}$ proteins), $1 \mathrm{mg}$ of AS IV fraction from $28^{\circ} \mathrm{C}$ or $40^{\circ} \mathrm{C}$ heat treated seedlings was added and the mixture was heated at $55^{\circ} \mathrm{C}$ or $65^{\circ} \mathrm{C}$ for indicated time period. After each heat treatment, samples were centrifuged at $23,000 \times \mathrm{g}$ for $15 \mathrm{~min}$. The denatured protein pellets were dissolved in $500 \mu \mathrm{l}$ of Laemmli's sample buffer, and $50 \mu \mathrm{l}$ of aliquots in duplicates were measured for radioactivity. Heat treatment at $55^{\circ} \mathrm{C}$ by addition of unlabeled $28^{\circ} \mathrm{C}$ AS IV $\left(-\Delta^{-}\right)$and $40^{\circ} \mathrm{C}$ AS IV $\left(-\Delta^{-}\right)$; at $65^{\circ} \mathrm{C}$ by addition of unlabeled $28^{\circ} \mathrm{C}$ AS IV $(-O)$ and $40^{\circ} \mathrm{C}$ AS IV (- --$)$. (B) Dose-response of unlabeled $28^{\circ} \mathrm{C}$ and $40^{\circ} \mathrm{C}$ AS IV for thermoprotection of $28^{\circ} \mathrm{C}{ }^{3} \mathrm{H}$-proteins from heat denaturation. Each sample with addition of $28^{\circ} \mathrm{C}$ AS IV $(-\circ)$ or $40^{\circ} \mathrm{C}$ AS IV $(-\triangle-)$ were heated at $55^{\circ} \mathrm{C}$ for $30 \mathrm{~min}$ and processed as indicated in (A) for measurement of denatured ${ }^{3} \mathrm{H}$-proteins.
Protection ability of HSPs without 15-18 kDa and with reduced levels of 68-70 $k D a, 24 k D a$ and $22 k D a-$ The $28^{\circ} \mathrm{C}$ AS IV had no HSPs, whereas the the $40^{\circ} \mathrm{C}$ AS IV had a complete set of HSPs. In addition the $40^{\circ} \mathrm{C} \rightarrow 45^{\circ} \mathrm{C}$ AS IV (seedlings that were first treated at $40^{\circ} \mathrm{C}$ for $3 \mathrm{~h}$ and then treated at $45^{\circ} \mathrm{C}$ for $30 \mathrm{~min}$ for induction of HSP association with organelles) was nearly depleted of the 15$18 \mathrm{kDa}$ and only somewhat reduced in the $68-70 \mathrm{kDa}$, $24 \mathrm{kDa}$ and $22 \mathrm{kDa}$ HSPs (Fig. 4). Using these AS IV protein fractions, we asked "are the 15-18 $\mathrm{kDa}$ and partial 68$70 \mathrm{kDa}, 24 \mathrm{kDa}$ and $22 \mathrm{kDa}$ HSPs involved in the protection against thermal denaturation?" The answer to this question is found in Table 3 . The data suggest that the 15$18 \mathrm{kDa}$ HSPs, which were present in the $40^{\circ} \mathrm{C}$ AS IV but

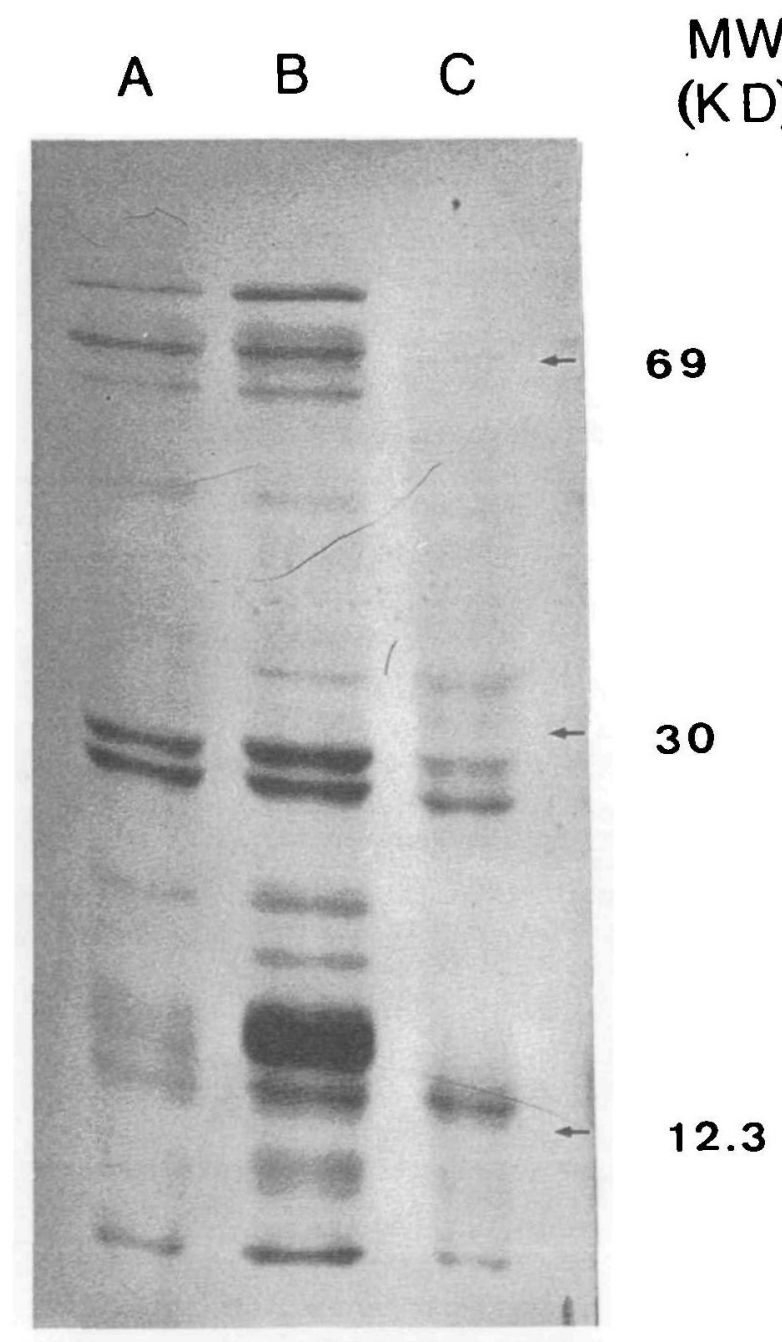

Fig. 4 Fluorograms of AS IV from three different treatments of soybean seedlings separated into protein components by SDSPAGE. (A) $40^{\circ} \mathrm{C} \rightarrow 45^{\circ} \mathrm{C}$ (seedlings were treated first at $40^{\circ} \mathrm{C}$ for $3 \mathrm{~h}$ and then at $45^{\circ} \mathrm{C}$ for $30 \mathrm{~min}$ for induction of HSP association with organelles), (B) $40^{\circ} \mathrm{C}$ and (C) $28^{\circ} \mathrm{C}$. 
Table 3 Stabilization of $28^{\circ} \mathrm{C}^{3} \mathrm{H}$-proteins against heat by addition of AS IV fraction

\begin{tabular}{|c|c|c|}
\hline \multirow{2}{*}{$\begin{array}{l}\text { Addition } \\
\text { AS IV }\end{array}$} & \multicolumn{2}{|c|}{$\mathrm{cpm}$} \\
\hline & $0.5 \mathrm{~h}$ & $1.0 \mathrm{~h}$ \\
\hline $28^{\circ} \mathrm{C}$ & $10,797 \quad(26 \%)$ & $12,253 \quad(29 \%)$ \\
\hline $40^{\circ} \mathrm{C}$ & $5,788(13.7 \%)$ & $7,743(18.3 \%)$ \\
\hline $40^{\circ} \mathrm{C} \rightarrow 45^{\circ} \mathrm{C}^{a}$ & $10,560 \quad(25 \%)$ & $12,730(30.2 \%)$ \\
\hline
\end{tabular}

To each $0.9 \mathrm{ml}$ of $28^{\circ} \mathrm{C}{ }^{3} \mathrm{H}$-proteins (containing $422,100 \mathrm{cpm}$ ), $1 \mathrm{mg}$ AS IV proteins from seedlings of three different heat treatment was added and heated at $55^{\circ} \mathrm{C}$ for indicated time period. After each heat treatment, the samples were centrifuged at $23,000 \times \mathrm{g}$ for $15 \mathrm{~min}$. The pellets were suspended in $250 \mu \mathrm{l}$ of Laemmli's sample buffer, and $25 \mu \mathrm{l}$ in duplicates were measured for radioactivity.

- Seedlings were treated first at $40^{\circ} \mathrm{C}$ for $3 \mathrm{~h}$ and then treated at $45^{\circ} \mathrm{C}$ for $30 \mathrm{~min}$ for induction of HSP association with organelles.

not in the $40^{\circ} \mathrm{C} \rightarrow 45^{\circ} \mathrm{C}$ AS IV, were required for protection. We can not rule out the possibilty that the 68$70 \mathrm{kDa}, 24 \mathrm{kDa}$ and $22 \mathrm{kDa}$ are required in small amounts.

\section{Discussion}

In our earlier experiments to test the model proposed by Minton et al. (1982) that the biological role for HSPs may stabilize heat-sensitive proteins, PRS from $40^{\circ} \mathrm{C}$ treated seedlings were used as a source of HSPs. We found the PRS from $40^{\circ} \mathrm{C}$ treated seedlings were $50 \%$ more stable to heat denaturation than that from $28^{\circ} \mathrm{C}$ treated seedlings (unpublished data, presented as a poster at the 1st International Congress of Plant Molecular Biology, Savannah, Ga, U.S.A. 1985). This provided some of the first evidence for a possible role of HSPs in the acquisition of thermotolerance in intact plants.

In the present investigation, we used a HSPs-enriched fraction to attack the same problem. During purification of HSPs by AS fractionation the whole set of HSPs was found in AS IV fraction, although a small percentage was found in AS III.

The HSPs-enriched AS IV was itself resistant to heat denaturation as measured by pelletability after heating.

The $40^{\circ} \mathrm{C}$ AS IV also showed significant ability to protect non-HSPs from heat denaturation. Under our standard assay conditions, $26 \%$ of a $28^{\circ} \mathrm{C}$ soluble proteins was rendered pelletable by a $30 \mathrm{~min}$ incubation at $55^{\circ} \mathrm{C}$. When $40^{\circ} \mathrm{C}$ AS IV was mixed with the $28^{\circ} \mathrm{C}$ soluble proteins, only $13 \%$ was pelletable after an identical heat treatment. In order to find more specifically which species of HSPs were contributing to the thermal stabilization, we used a protocol of seedling heat treatment $\left(40^{\circ} \mathrm{C} \rightarrow 45^{\circ} \mathrm{C}\right)$ which depleted $15-18 \mathrm{kDa}$ and reduced $68-70 \mathrm{kDa}, 24 \mathrm{kDa}$ and
$22 \mathrm{kDa}$ HSPs in PRS (Lin et al. 1984). When this preparation of $40^{\circ} \mathrm{C} \rightarrow 45^{\circ} \mathrm{C}$ AS IV was added in our standard assay the effectiveness in preventing normal non-HSPs from heat denaturation was lost entirely. The finding suggest that $15-18 \mathrm{kDa}$ and perhaps $68-70 \mathrm{kDa}, 24 \mathrm{kDa}$ and $22 \mathrm{kDa}$ HSPs contribute most to providing thermostability.

Recently we were able to demonstrate that isolated mitochondria are thermoprotected in vitro for $\mathrm{O}_{2}$ uptake and tightly coupld to ATP formation at $42.5^{\circ} \mathrm{C}$ by association of $15-18 \mathrm{kDa}$ and partial $68-70 \mathrm{kDa}, 24 \mathrm{kDa}$ and $22 \mathrm{kDa}$ HSPs in soybean seedlings (Chou et al. 1989). While it appears that association of $15-18 \mathrm{kDa}$ and perhaps 68-70 kDa, $24 \mathrm{kDa}$ and $22 \mathrm{kDa}$ HSPs with organelles during HS provides the basis of in vitro experiment for thermoprotection, the preparation of soluble proteins (PRS) we used in this study might contain some of the proteins from the organelles to which these HSPs are providing thermoprotection. We are now studying which component of the soluble proteins is preferentially thermoprotected by these HSPs.

The role of HSPs we observed here in stabilizing proteins by maintaining in a soluble, undenatured form of proteins may be analogous to the chaperones proposed by Hemmingsen et al. (1988) recently.

This work was supported by National Science Council, Taiwan, R.O.C. under Grant NSC76-0201-B002-11 to C. Y. Lin. We thank to Drs. Joe E. Varner and Anthony, H. C. Huang for critical reading of the manuscript.

\section{References}

Arrigo, A. P. and Ahmad-Zadeh, C. (1981) Immunofluorescence localization of the small heat shock proteins (hsp 23) in salivary gland cells of Drosophila melanogaster. Mol. Gen. Genet. 184: 73-79.

Arrigo, A. P., Fakan, S. and Tissieres, A. (1980) Localization of the heat-induced proteins in Drosophila melanogaster tissue culture cells. Dev. Biol. 78: 86-103.

Barnett, T., Altschuler, M., McDaniel, C. N. and Mascarenhas, J. P. (1980) Heat shock induced proteins in plant cells. Dev. Genet. 1: 331-340.

Chou, M., Chen, Y. M. and Lin, C. Y. (1989) Thermotolerance of isolated mitochondria associated with heat shock proteins. Plant Physiol. (in press).

Cooper, P. and Ho, D. T-H. (1987) Intracellular localization of heat shock proteins in maize. Plant Physiol. 84: 1196-1203.

Gerner, E. W. and Schneider, M. L. (1975) Induced thermal resistance in HeLa cells. Nature 256: 500-503.

Hemmingsen, S. M., Woolford, C., van der Vies, S. M., Tily, K., Dennis, D. T., Georgopoulos, C. P., Hendrix, R. W. and Ellis, R. J. (1988) Homologous plant and bacterial proteins 
oligomeric protein assembly. Nature 333: $330-334$.

Key, J. L., Lin, C. Y., Chen, Y. M. (1981) Heat shock proteins of higher plants. Proc. Natl. Acad. Sci. USA 78: 3526-3530.

Laemmli, U. K. (1970) Cleavage of structural proteins during the assembly of the head of bacteriophage $T_{4}$. Nature 227: 680685.

Levinger, L. and Varshavsky, A. (1981) Heat shock proteins of Drosophila are associated with nuclease-resistant, high salt-resistant nuclear structures. J. Cell. Biol. 90: 793-796.

Li, G. C. and Werb, Z. (1982) Correlation between synthesis of heat shock proteins and development of thermotolerance in Chinese hamster fibroblasts. Proc. Natl. Acad. Sci. USA 78: 3218-3222.

Lin, C. Y,, Roberts, J. K. and Key, J. L. (1984) Acquisition of thermotolerance in soybean seedlings: synthesis and accumulation of heat shock proteins and their cellular localization. Plant Physiol. 74: 152-160.

Loomis, W. F. and Wheeler, S. (1980) Heat shock response of Dictyostelium. Dev. Biol. 79: 399-408.

Lowry, O. H., Rosebrough, N. J., Farr, A. L. and Randoll, R. J. (1951) Protein measurement with the Folin phenol reagent. $J$. Biol. Chem. 193: 265-275.

Mans, R. J. and Novelli, G. D. (1961) Measurement of the incorporation of radioactive amino acids into protein by a filter paper disk method. Arch. Biochem. Biophys. 94: 48-53.

McAlister, L. and Finkelstein, D. B. (1980) Heat shock proteins and thermal resistance in yeast. Biochem. Biophys. Res. Commun. 93: 819-824.

Minton, K. W., Karmin, P., Hahn, G. H. and Minton, A. P. (1982) Nonspexific stabilization of stress-susceptible proteins by stress-resistant proteins: a model for the biological roles of heat shock proteins. Proc. Natl. Acad. Sci. USA. 79: 71077111.

Mitchell, H. K. and Lipps, L. S. (1975) Rapidly labeled proteins on the salivary gland chromosome of Drosophila melanogaster. Biochem. Genet. 13: 585-602.

Mitchell, H. K., Moller, G., Petersen, N. S. and Lipps-Sarminto, L. (1979) Specific protection from phenocopy induction by heat shock. Dev. Genet. 1: 181-192.

Petersen, N. S. and Mitchell, H. K. (1981) Recovery of protein synthesis after heat shock: prior heat-treatment affects the ability of cells to translate mRNA. Proc. Natl. Acad. Sci. USA 78: 1708-1711.

Schlesinger, M. J., Ashburner, M. and Tissieres, A. (1982) Heat Shock: from Bacteria to Man. p. 440. Cold Spring Harbor Laboratory, Cold Spring Harbor, New York.

Valazquez, J. M., DiDomenico, B. J. and Lindquist, S. (1980) Intercellular localization of heat shock proteins in Drosophila. Cell 20: 679-689.

Vincent, M. and Tanquay, R. M. (1979) Heat shock induced proteins present in the cell nucleus of Chironomus tentans salivary gland. Nature 281: 501-503.

(Received July 28, 1988; Accepted March 2, 1989) 